\title{
KARAKTERISTIK MORFOMETRIK DAN FAKTOR KONDISI KERANG TOTOK (Polymesoda erosa) DI HUTAN MANGROVE DESA NUSAJAYA KECAMATAN WASLEI SELATAN KABUPATEN HALMAHERA TIMUR MALUKU UTARA ${ }^{1}$
}

\author{
Morphometical Characteristicsa and Conditional Factor Of Clam Polymesoda erosa In \\ Mangrove Tree of Nusajaya Village Sub-District Of Shouth Waslei East Halmahera \\ District North Maluku
}

\section{Alfrina Rumbiak ${ }^{2}$, Ir.Jan F.W.S.Tamanampo ${ }^{3}$, Ir Gaspar D. Manu ${ }^{3}$ ABSTRACT}

Clam, Polymesoda erosa is species that live in sandy and muddy substrata of mangrove ecosystem. The aims of this study are to look at the relationship of the shell length and width,body thiekness, body weight and organ weight based on class size to determine the growth. The study also was designed to reveal the conditional factor based on the clam class size. The samples were collected during the day at lowest tide in January 2014. The total is 153 individuals of Polymesoda erosa clam were collected during the study. The result shows thare is a strong positive relationship between body lenght and body weight as shown within the regression analysis with intercept (a) $=0,470779$, regression coefficient $(b)=0,69095$ and correlation coefficient $(r)=0,406357$. Based on the $r$ value, it can be concluded that there is strong relationship regarding the length and weight increment as much as $40,63 \%$.

Keywords : Characteristics Morphometrics and Shellfish totok condition factor Nort Maluku

\section{ABSTRAK}

Kerang totok (Polymesoda erosa) adalah salah satu jenis moluska dalam kelas bivalvia yang hidup di ekosistem mangrove pada daerah yang bersubstrat pasir dan berlumpur. Penelitian ini bertujuan. mengetahui kisaran ukuran panjang cangkang,,lebar cangakang, tubuh, berat tubuh, dan berat organ lunak, selanjutnya mengetahui pertambahan panjang, lebar cangkang, tebal tubuh, berat tubuh, dan berat organ lunak berdasarkan kelas ukuran, dan juga mengetahui hubungan pertumbuhan panjang cangkang, dan berat cangkang, dan mengetahui faktor kondisi kerang di setiap kelas ukuran. Pengambilan sampel di lakukan pada siang hari saat surut terendah pada bulan januari 2014. Berdasarkan kegiatan penelitian di wilayah pesisir Desa Nusajaya Kecamatan Waslei Selatan Kabupaten Halmahera Timur Maluku Utara, dikumpulkani 153 individu kerang totok (Polymesoda erosa). Hasil analisis regresi menunjukkan bahwa setiap pertambahan panjang cangkang akan diikuti dengan pertambahan berat secara proporsional mengikuti nilai Intercept $(\mathrm{a})=0.470779$, dan koefisien regresi $(\mathrm{b})=$ 0,690957 . Niilai koefisien korelasi $(r)=0.406357$ menyatakan adanya korelasi positif yang menerangkan terdapat keeratan hubungan antara pertambahan panjang cangkang dengan pertambahan berat berat tubuh sebesar $40.63 \%$

Kata kunci :Karakteristik Morfometrik dan Faktor kondisi KerangTotok Maluku utara

\author{
${ }^{1}$ Bagian dari skripsi \\ ${ }^{2}$ Mahasiswa Program Studi Manajemen Sumberdaya Perairan FPIK-UNSRAT \\ ${ }^{3}$ Staf pengajar Fakultas Perikanan dan Ilmu Kelautan Universitas Sam Ratulangi
}




\section{PENDAHULUAN}

Indonesia merupakan Negara kepulauan yang memiliki kawasan pesisir yang sangat luas. Wilayah pesisir yaitu daerah tepi laut yang meliputi pantai atau daerah pasang surut, hutan mangrove dan tambak (Rososoedarmon1986).Selanjutnya dikatakan bahwa wilayah ini berpotensi sebagai daerah pengembangan berbagai kegiatan perikanan. oleh karena memiliki sumberdaya perairan yang beranekaragam.

Moluska adalah salah satu kelompok avertebrata terbesar kedua setelah filum Arthropoda, dimana sekitar 80.000 spesies yang termasuk dalam kelompok ini tersebar luas di berbagai habitat, yaitu daratan, perairan tawar maupun perairan laut (Ruppert dan Barnes, 1994). Mereka dapat hidup di berbagai habitat oleh karena kamampuan adaptasinya yang sangat tinggi. Kemapuan adaptasi ini ditunjukkan oleh beragam jenis moluska yang hidup di daerah intertidal yang harus dapat menetolerir level suhu dan salinitas yang naik turun secara ekstrim (Nybaken, 1988).

$\mathrm{Di}$ wilayah Indo-Pasifik, khususnya di perairan Indonesia dikenal sebagai daerah yang termasuk kaya akan berbagai jenis moluska, bahkan dianggap sebagai pusat penyebaran spesies moluska bagi perairan-perairan sekitarnya (Hari, 1999). Selanjutnya menurut (Bceom, 2003) di Indonesia terdapat sekitar 3400 moluska di mana $75 \%$ hidup di laut diperkirakan baru 20\% yang dapat dimanfaatkan sebagai sumber makanan, perhiasan atau bahan baku yang digunakan untuk produk lainnya.

Kerang totok (Polymesoda erosa) adalah salah satu jenis moluska dalam kelas Bivalvia yang hidup di ekosistem mangrove dan banyak dijumpai di ekosistem mangrove Indo-Pasifik Barat mulai dari India, Malaysia, Indonesia, Thailand, Vietnam, Burma, Philipina, (Morton, 1984). Kerang ini dimanfaatkan oleh masyarakat setempat sebagai sumber pangan untuk meningkatkan kebutuhan gizi keluarga mereka selain itu juga diperdagangkan sampai keluar daerah.. Daerah perairan pantai Desa Nusajaya Kabupaten Halmahera Timur merupakan daerah yang terdapat ekosistem khas tropis yaitu ekosistem mangrove, rumput laut dan terumbu karang yang merupakan habitat dari berbagai biota laut khususnya kerang totok (Polymesoda erosa. Kerang ini bernilai ekonomis penting dan telah dimanfaatkan sebagai sumber pendapatan dan kebutuhan gizi bagi masyarakat setempat.. Perairan pantai desa ini memiliki profil pantai yang landai dengan subsrat berpasir sampai pasir berlumpur, yang merupakan habitat dari berbagai jenis bivalvia, di antaranya Kerang totok. untuk itu perlu dilakukan penelitian tentang sumberdaya hayati ini yang menyangkut pertumbuhan dan factor kondisi kerang.. Berdasarkan hal tersebut maka dibutuhkan data tentang karakter morfometrik menyangkut panjaqng cangkang, lebar cangkang, tebal tubuh, berat tubuh (berat cangkang + berat organ dalam).

Penelitian ini bertujuan Mengetahui kisaran ukuran panjang, lebar camgkang, tebal tubuh, berat tubuh, dan berat organ lunak berdasarkan kelas ukuran, Mengetahui pertambahan panjang, lebar cangkang, tebal tubuh, berat tubuh, dan berat organ dalam berdasarkan kelas ukuran, Mengetahui hubungan pertumbuhan panjang cangkang dan berat cangkang, Mengetahui faktor kondisi kerang di setiap kelas ukuran

\section{MATERIAL DAN METODE}

Penelitian telah dilakukan pada bulan januari 2013, di pantai Desa 
Nusajaya Kecamatan Waslei Selatan Kabupaten Halmahera Timur Maluku Utara (Lampiran 1). Kegiatan pengambilan sampel di lapangan dan pekerjaan di Laboratorium untuk mendapatkan data penelitian dilakukan selama 2 bulan. Pengumpulan data dan analisis data dilakukan selama 1 bulan Pengambilan sampel dilakukan dengan menelusuri daerah mangrove yang berpasir dan berlumpur. Sampel kerang totok yang ditemukan dikumpulkan dalam ember plastik, selanjutnya setiap individu kerang dibersihkan dengan air laut, dimasukan dalam beberapa kantong plastik kemudiian dikumpulkan dalam "ice box" dan dibawa ke laboratorium untuk dilakukan pengamatan morfologi untuk identifikasi, dan pengukuran karakter morfometrik. Pekerjaan Laboratorium untuk memperoleh data meliputi pengukuran panjang tubuh, lebar tubuh dan tebal tubuh. Pengukuran panjang, lebar dan tebal untuk setiap individu mengunakan alat ukur "vernier caliper" berketilitian $0,01 \mathrm{~mm}$. Selanjutnya pengukuran, berat organ lunak dan berat tubuh (berat cangkang + berat organ lunak) setiap individu dilakukan dengan mengunakan timbangan digital berketilitian 0,01 gram. Alat bantu lain dalam pekerjaan Laboratorium adalah satu set alat bedah untuk membuka cangkan dan mengeluarkan isi cangkang berupa daging dan organ-organ dalam lainnya.

\section{Srtuktur Ukuran}

Untuk melihat sebaran ukuran berdasarkan panjang cangkang, lebar cangkang, tebal tubuh, berat tubuh, dan berat organ lunak, maka data hasil pengukuran dibuat beberapa kelas ukuran. Penentuan banyaknya selang kelas yang akan dibentuk menggunakan kaidah empirik yang disebut Kaidah Sturge (Nasotion dan Barizi, 1980) yaitu jumlah data (n) kurang dari 250 dibuat dalam 9 Kelas.
Sedangkan data (n) $\geq 250$ menggunakan rumus $1+3.3 \log n$.

\section{Hubungan Panjang Tubuh dan Berat Tubuh}

Untuk menganalisis hubungan panjang dan berat digunakan persamaan menurut Hile dalam Effendie (1979) :

$$
\begin{aligned}
& \mathbf{W}=\mathbf{a L}^{\mathbf{b}} \\
\text { Di mana }: \mathbf{W} & =\text { Berat Tubuh (gram) } \\
\mathrm{L} & =\text { Panjang Tubuh }(\mathrm{mm}) \\
\mathrm{a} & =\text { Intercept } \\
\mathrm{b} & =\text { Koefisien regresi }
\end{aligned}
$$

Estimasi parameter a dan b diperoleh dengan merubah persamaan linier sederhana melalui trasformasi Logaritma

\section{$\log W=\log a+b \log$}

Selanjutnya untuk melihat apakah model linier regresi tersebut dapat dijadikan penduga hubungan berat tubuh dengqn panjang cangkang, maka model uji dengan analisis garis regresi sebagai berikut (Sutrisno, 1994) :

Tabel 1 Analisis Variasi Garis Regresi.

\begin{tabular}{|c|c|c|c|c|}
\hline $\begin{array}{c}\text { Sumber } \\
\text { Variasi }\end{array}$ & Db & JK & RK & Freg \\
\hline Regresi & 1 & $\frac{(\Sigma x y)^{2}}{\Sigma x^{2}}$ & $\frac{\mathrm{JK}_{\text {reg }}}{\mathrm{db}_{\text {reg }}}$ & $\mathrm{RK}_{\text {reg }}$ \\
\hline Residu & $\begin{array}{c}\mathrm{n}- \\
2\end{array}$ & $\frac{(\Sigma x y)^{2}}{\mathrm{~N}}$ & $\frac{\mathrm{JK}_{\text {reg }}}{\mathrm{db}_{\text {reg }}}$ & $\mathrm{RK}_{\text {reg }}$ \\
\hline Total & $\mathrm{n}-$ & $\Sigma \mathrm{y}^{2}$ & & \\
\hline
\end{tabular}

$\mathrm{JK}=$ Jumlah Kuadrat

$\mathrm{RK}=$ Rerata Kuadrat garis regresi

$F=$ Harga bilangan $F$ untuk garis regresi

Pengambila keputusan jika

Fhit $\left\{\begin{array}{l}\leq \mathrm{Ftab}(0,05) \text { dan } 0,01) \text { model ditolak } \\ \text { Etab }(0,05) \text { dan } 0,01) \text { model diterima }\end{array}\right.$

Menurut Nasoetion dan Barizi (1980), untuk melihat korelasi antara panjang tubuh $(\mathrm{x})$ dan berat tubuh (y) dapat dianalisis sebagai berikut 


$$
r x y=\frac{\Sigma x y}{\sqrt{\Sigma x^{2}-\Sigma y^{2}}}
$$

\section{Faktor Kondisi}

Faktor kondisi yang sering kali disebut juga faktor $\mathrm{K}$ merupakan terapan dari analisis hubungan panjang berat dan merupakan derivat yang penting dalam pertumbuhan bivalvia. Dalam hal ini faktor kondisi dapat mengambarkan baik tidaknya kondisi bivalvia dilihat dari segi kepasitas fisik untuk kelansungan hidup (survival) dan reproduksi.

Untuk melihat faktor kondisi pada bivalvia digunakan formula menurut Effendie (1979) yaitu : .Kn $=\frac{\mathrm{W}}{\mathrm{aL}^{\mathrm{b}}}$

$$
\begin{aligned}
& \text { Dimana : } \mathrm{Kn}=\text { Faktor kondisi relatif } \\
& \mathrm{W}=\text { Berat tubuh (gr) } \\
& \mathrm{L}=\text { Panjang tubuh } \\
& a, b=\text { Konstanta }
\end{aligned}
$$

\section{HASIL DAN PEMBAHASAN}

\begin{abstract}
Sampling yang dilakukan terhadap populasi kerang totok di perairan Desa Nusajaya Kecamatan Waslei Selatan Kabupaten Halmahera Timur. memperoleh 153 individu yang berada pada daerah yang bersubsrat berpasir dan berlumpur.
\end{abstract}

\section{Struktur Ukuran \\ Panjang Cangkang}

Data ukuran panjang cangkang berdasarkan kelas ukuran (Tabel 02) yang ditampilkan dalam bentuk Histogram menunjukkan bahwa jumlah individu terbanyak terdapat pada Kelas Ukuran ke 6 ( 30 individu dengan rerata ukuran panjang cangkang $51.56 \mathrm{~mm}$ dan ke 7 (32 individu dengan rerata ukuran $58.79 \mathrm{~mm}$ ). Hal ini berarti pula terdapat $40.52 \%$ kerang dengan ukuran panjang cangkang 49.22 $55.24 \mathrm{~mm}$ dan 55.25-61.28 $\mathrm{mm}$ mendominasi ukuran dari populasi kerang yang terdapat di alam. Sedangkan ukuran panjang cangkang pada Kelas 8 (62,23 -66.24 mm) dan 9 ( $69.22-74.27 \mathrm{~mm}$ ) sebesar $10.48 \%$ adalah populasi yang tertsisa dari adanya eksploitasi. Data pertambahan panjang cangkang berdasarkan kelas ukuran menunjukkan adanya kenaikan pertambahan panjang cangkang yang berflutuasi kecil pada setiap bertambahnya kelas ukuran tertera pada gambar 02 dan 03.

\section{Lebar Cangkang}

Data ukuran Lebar cangkang berdasarkan kelas ukuran (Table 05) yang ditampilkan dalam bentuk Histogram menunjukkan bahwa jumlah individu terbanyak terdapat pada Kelas Ukuran ke 5 ( 43 individu dengan rerata ukuran Lebar cangkang $42.57 \mathrm{~mm}$ dan ke 6 (30 individu dengan rerata ukuran lebar cangkang $50.08 \mathrm{~mm}$ ). Hal ini berarti pula terdapat $47.71 \%$ kerang dengan ukuran lebar cangkang dengan ukuran tersebut mendominasi ukuran dari populasi kerang yang terdapat di alam. Sedangkan ukuran Lebar cangkang pada Kelas 7, 8, dan 9 (sebesar $18.95 \%$ adalah populasi berkurang oleh adanya eksploitasi. Data pertambahan Lebar cangkang berdasarkan kelas ukuran menunjukkan adanya kenaikan pertambahan panjang cangkang yang berflutuasi kecil pada setiap bertambahnya kelas ukuran terterah pada gambar 08 dan 09.

\section{Hubungan Panjang Berat}

Hasil analisis regresi untuk melihat apakah terdapat hubungan yang nyata antara panjang tubuh dengan berat tubuh, di peroleh nilai Intercept $(a)=0.470779$, dan koefisien regresi $=0.690957$, disajikan dalam persamaan regresi linier sederhana :

Analisis keragaman untuk melihat apakah model regresi tersebut di atas dinyatakan diterima atau ditolak 
tertera pada lampiran 2. Hasil analisis ragam menunjukan bahwa $\mathrm{F}_{\text {hit }}=$ $103.3615>$ F $0.05(152)=3.9034$ hal ini menerangkan bahwa persamaan regresi yang terbentuk diterima untuk menyatakan adanya hubungan yang nyata antara pertambahan berat tubuh dengan pertambahan panjang tubuh, atau pertambahan panjang cangkang akaqn selalu diikuti oleh pertambahan berat. Demikian pula dengan nilai koefisien korelasi $(r)=0.406357$ yang menyatakan terdapat korelasi positif antara berat tubuh dan panjang tubuh atau adanya keeratan hubungan antara pertambahan panjang dan pertamabahan berat sebesar $40.63 \%$.

\section{Berat Daging}

Data ukuran berat organ lunak (daging) berdasarkan kelas ukuran (Tabel 06) yang ditampilkan dalam bentuk Histogram menunjukkan bahwa jumlah individu terbanyak terdapat pada Kelas Ukuran ke 2 ( 35 individu dengan rerata berat daging sebesar $4.90 \mathrm{grm} / \mathrm{individu}$ dan ke 3 (32 individu dengan rerata berat daging sebesar $7.01 \mathrm{grm} / \mathrm{individu}$ ) . Hal ini berarti pula terdapat $43.78 \%$ kerang mendominasi ukuran dari populasi kerang yang terdapat di alam. Sedangkan kerang dengan berat daging 14.09 - 18.50 gram/individu di alam berkurang hingga $8.48 \%$ oleh adanya eksploitasi. Data pertambahan Berat daging berfluktuasi antara $1.41-2.54$ gram/individu pada setiap kelas ukuran tertera pada gambar 11 dan 12.

\section{Faktor Kondisi \\ Faktor Kondisi}

Hasil analisis factor kondisi kerang totok ( $P$ erosa) berdasarkan kelas ukuran tertera (Tabel 07) dan dalam bentuk grafik (Gambar 13). Faktor kondisi setiap kelas ukuran bervariasi antara 3.86-10.29.

Berdasarkan tampilan faktor kondisi berdasarkan kelas ukuran panjang dan berat menujukkan bahwa faktor kondisi kerang cukup baik yang mana adanya kenaikan factor kondisi pada setiap kelas ukuran. Bila dikaitkan dengan habitat dimana kerang ini hidup, maka dapat diduga bahwa faktor lingkungan fisik dan ketersediaan makanan memegang peran penting bagi kelangsungan hidup dan pertumbuhan kerang totok $(P$ erosa). Nilai factor kondisi kerang yang menujukkan adanya kenaikan pada setiap ukuran menerangkan bahwa populasi kerang cukup sehat di habitatnya.

\section{KESIMPULAN DAN SARAN}

\section{Kesimpulan}

Berdasarkan hasil penelitian yang dilakukan di pantai Desa Nusajaya Kecamata Waslei Selatan Kabupaten Halmahera Timur Maluku Utara dapat ditarik kesimpulan

1. Hasil pengukuran karakter morfometrik menunjukkan Kisaran ukuran panjang cangkang $(17,03 \mathrm{~mm}-74,27$ $\mathrm{mm})$, lebar cangkang $(21,31 \mathrm{~mm}$ - 67,07 mm), tebal tubuh $(12,26$ $\mathrm{mm}-31,41 \mathrm{~mm})$, berat tubuh $(19,24$ gr $-47,37 \mathrm{gr})$,berat organ lunak $(2,11 \mathrm{gr}-19,37 \mathrm{gr})$

2. Pertambahan panjang cangkang, berat cangkang, lebar cangkang, tebal tubuh, dan berat organ lunak berdasarkan kelas ukuran menunjukkan kenaikan yang berfluktuasi.

3. Hasil analisis regresi dan korelasi menunjukkan bahwa setiap pertambahan panjang cangkang akan diikuti oleh pertambahan berat dengan keeratan hubungan $r=0,4063$.

4 Faktor kondisi kerang totok (Polymesoda erosa) menunjukkan adanya kenaikan nilai faktor kondisi berdasarkan kelas ukuran yang berarti pula 


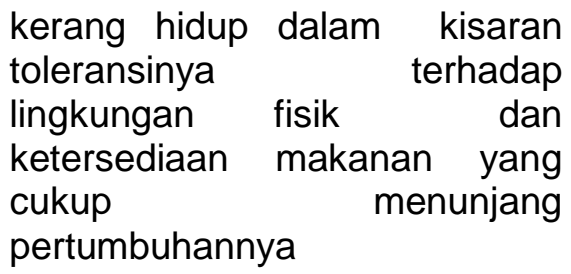

\section{Saran}

1. Perlu adanya penelitian tentang Tingkat Kematangan Gonad dan Indeks Kematangan Gonad untuk mengetahui perkembangan gonad dan musim memijahan

2. Perlu adanya pengaturan ukuran yang dapat dipanen dimulai dengan peraturan desa.

\section{DAFTAR PUSTAKA}

Ali,M, S. 2007. Kondisi Kerang Geloina Pasca Tsunami di Perairan Ekosistem Mangrove Pesisir Barat Kabupaten Aceh Besar. Prosiding Seminar Nasional Moluska dalam Penelitian, Konservasi dan Ekonomi : 109120.

Bceom. 2003. The Ecology of Mangrove and of The Common Asiatic Clam (Polymesoda erosa) in Segara Anakan. PT. Ardes Perdana dan PT. BhawanaPrasasta. Repubic of Indonesia Ministry of Home Affairs. Directorate General of Regional Development, 3937.

Del Norte-Campos AGC, 2004. Some aspects of the subset elongate clam Gari elongate (Laramarck 1818) (Mollusca, Palecypoda: Psammobiidae) from the Beate Bay area, West Central Philippines. Asian publ.Sci. 17: 299-321

Dwiono, S. A. P. 2003. Pengenalan Kerang Mangrove, Geloina erosa dan Geloinaexpansa.
Balitbang Sumber Daya Laut, Pusat Penelitian OseanografiLIPI, Jakarta. Oceana: 31-38

Effedie M. I. 1979. Metode Biologi Perikanan. Yayasan Sri Dewi, Bogor. 112 Hal.

Hari, H. 1999. Beberapa Aspek Bioekologi Komunitas Bivalvia di Kawasan Hutan Mangrove Teluk Kulisusu, Kab. Muna, Prop. Sulawesi Tenggara. Tesis. Program Pascasarjana. IPB. Bogor. 105.

Levinton, J. S. 1991. Variable Feeding Behavior in Three Species of Macoma (Bivalvia : Tellinacea) as a Response to Water Flow and Sediment Transport. Mar. Biol. 110 : 375383.

Morton, B. 1984. A Review of Polymesoda erosa (geloina). (Geloina) Gray 1842 (Bivalvia: Corbiculidae) from Indo-Pasific Mangrove. Journal Asian Marine Biology. 77-86

Nasotion A.H dan Barizi, 1980. Metode Statistika. PT. Gramedia Jakarta.

Nybakken, J. W. 1988. Biologi laut. Suatu Pendekatan Ekologi. Edisi Kedua. PT. Gramedia. Jakarta. 459 hal.

Resosoedarmon, R. S., K. Kartawinata, A. Soegiarto. 1986. Pengantar Ekologi Penerbit CV. Remaja Karya, Bandung. 174 hal.

Ruppert E. E. dan R. D. Barnes. 1994. Invetebrate Zoology, Zixth Edition. Saunders College Publ. Fort Wort, USA. 1056 hal. 
Sutrisno Hadi, 1994 Analisis Regresi.

Penerbit Andi Offset.

Yogyakarta.

Widowati, I., J. Suprijanto, R. Hartati, dan S. A. P. Dwiono. 2005. Hubungan Dimensi Cangkang dengan Berat Kerang Totok Polymesoda erosa (Bivalvia : Corbiculidae) dari Segara Anakan Cilacap, Prosiding SeminaNasional Biologidan Akuakultur Berkelanjutan, Fakultas Biologi Program Sarjana Perikanan dan Kelautan Universitas Jendral Soedirman, Purwokerto. 48-50 hal.. 
Peta lingkungan Pantai Indonesia. Lembar : LIPI 2417-03. Bakonsurtanal 1995.

\section{PETA MALUKU UTARA}

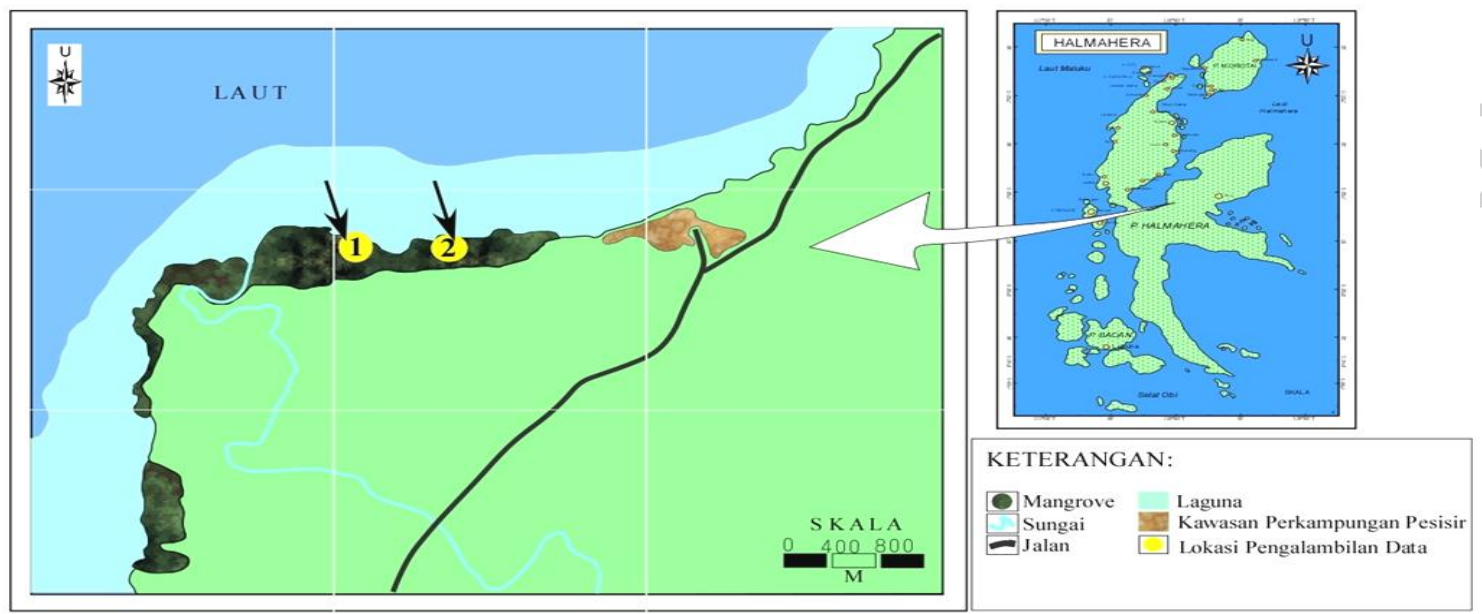

Gambar 1. Peta lokasi pengambialn data penelitian di Pantai Desa Nusajaya Kecamatan Waslei Selatan Kabupaten Halmahera Timur Maluku Utara.

\begin{tabular}{|c|c|c|c|c|}
\hline Kelas & Frekuensi & Persentase & Rerata PC & $\Delta$ PC \\
\hline 1 & 17 & 11,11 & 20.55 & - \\
\hline 2 & 12 & 7,84 & 26.88 & 6,33 \\
\hline 3 & 12 & 7,84 & 32.09 & 5,21 \\
\hline 4 & 19 & 12,41 & 39.88 & 7,79 \\
\hline 5 & 15 & 9,80 & 45.09 & 5,21 \\
\hline 6 & 30 & 19,60 & 51.56 & 6,47 \\
\hline 7 & 32 & 20,9 & 58.79 & 7,23 \\
\hline 8 & 7 & 4,57 & 64.5 & 5,71 \\
\hline 9 & 9 & 5,88 & 71.6 & 7,1 \\
\hline Total & $\mathbf{1 5 3}$ & $\mathbf{1 0 0}$ & & \\
\hline
\end{tabular}

Tabel 2. Persentase panjang cangkang, rata-rata panjang cangkang pertambahan panjang cangkang, berdasarkan kelas ukuran 


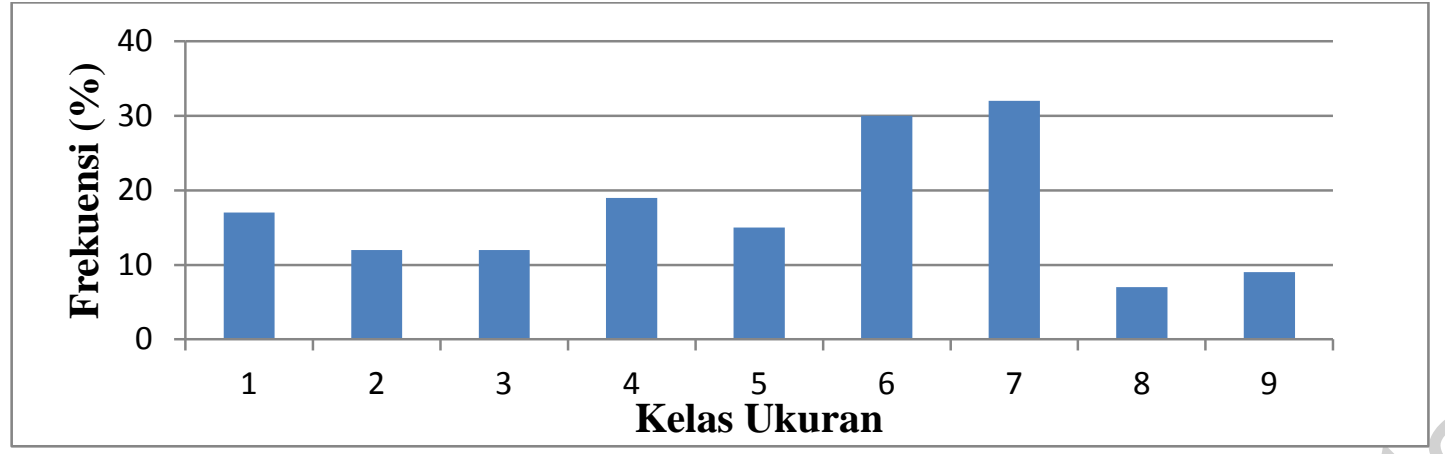

Gambar 02. Persentase sebaran panjang cangkang berdasarkan kelas ukuran

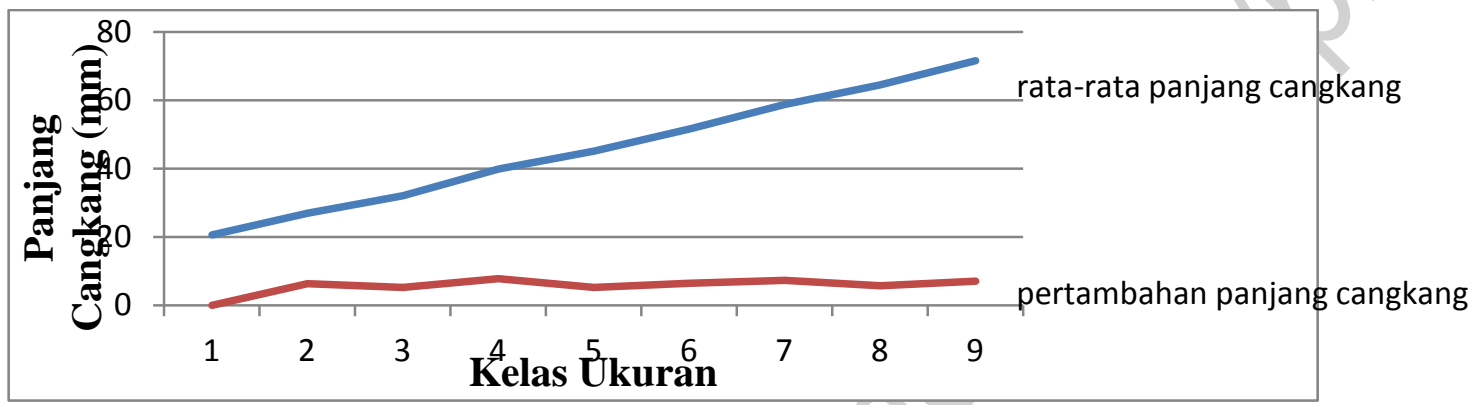

Gambar 03.Rata-rata panjang cangkang dan pertambahan panjang cangkang berdasarkan kelas ukuran

\begin{tabular}{|c|c|c|c|c|}
\hline Kelas & Frekuensi & Persentase & Rerata LC & $\Delta$ LC \\
\hline 1 & 7 & 4,57 & 22.43 & - \\
\hline 2 & 15 & 9,80 & 28.54 & 6,11 \\
\hline 3 & 21 & 4,63 & 32.39 & 3,85 \\
\hline 4 & 8 & 5,22 & 38.86 & 6,47 \\
\hline 5 & 43 & 28,10 & 42.57 & 3,71 \\
\hline 6 & 30 & 19,60 & 50.08 & 7,51 \\
\hline 7 & 12 & 7,84 & 54.83 & 4,75 \\
\hline 8 & 14 & 9,15 & 59.94 & 5,11 \\
\hline 9 & 3 & 1,96 & 65.06 & 5,12 \\
\hline Total & 153 & & & \\
\hline
\end{tabular}

Tabel 05. Persentase Lebar Cangkang, Rata-rata dan Pertambahan Lebar Cangkang Berdasarkan kelas ukuran 


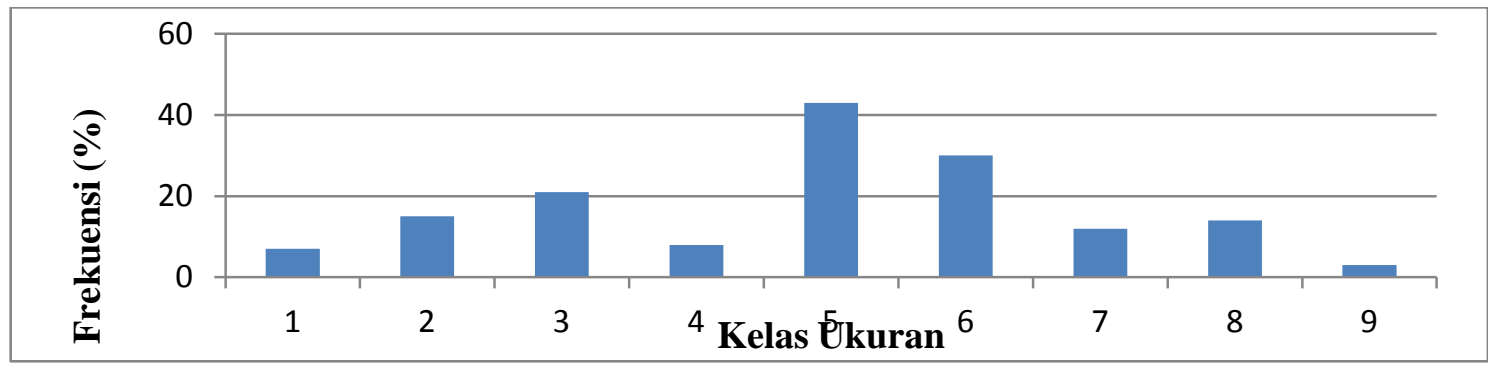

Gambar 08. Persentase Sebaran Lebar Cangkang Berdasarkan Kelas Ukuran

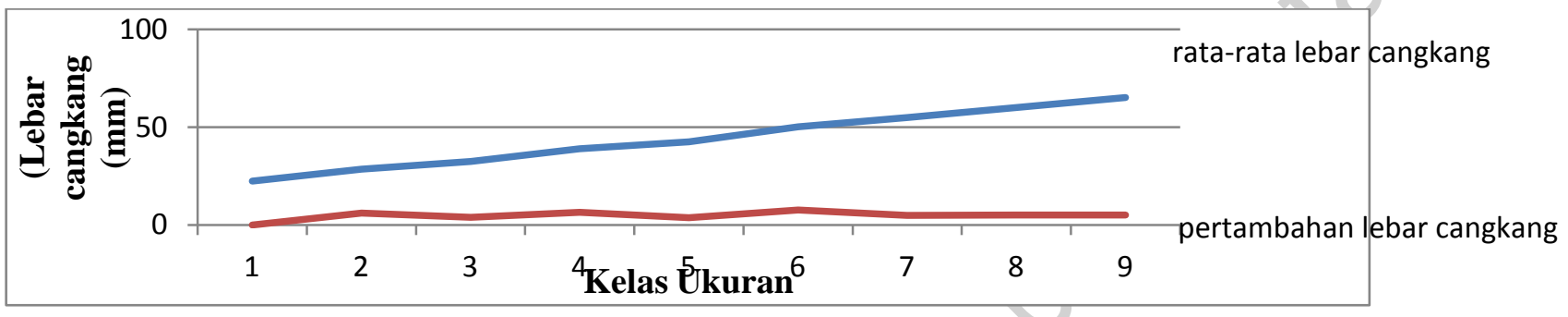

Gambar 09. Rata-rata Lebar Cangkang Dan Lebar cangkang Berdasarkan Kelas ukuran

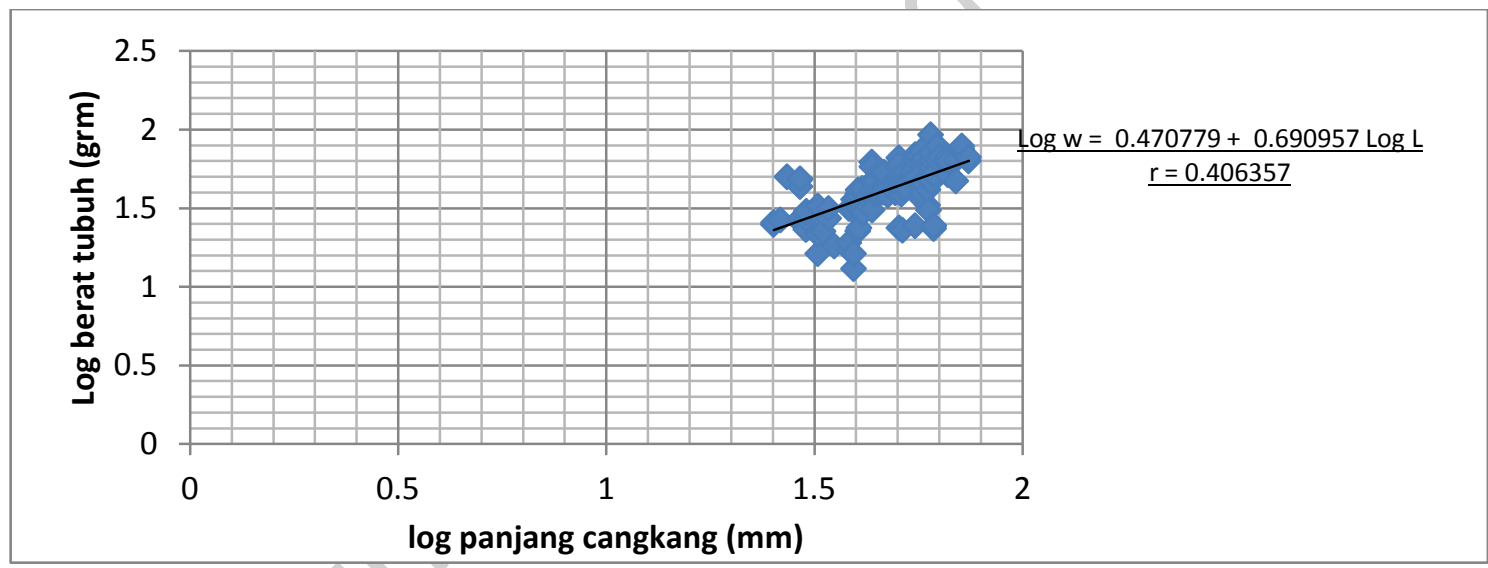

Gambar 10. Hubungan panjang cangkang dan Berat Tubuh kerang (Polymesoda erosa)

\begin{tabular}{|c|c|c|c|c|}
\hline Kelas & Frekuensi & Persentase & Rerata BD & $\Delta$ BD \\
\hline 1 & 19 & 12.4183 & 3,1516 & - \\
\hline 2 & 35 & 22.8758 & 4.9025 & 1.7509 \\
\hline 3 & 32 & 20.9150 & 7.0047 & 2.1022 \\
\hline 4 & 19 & 12.4183 & 8.6995 & 1.6948 \\
\hline 5 & 17 & 11.1111 & 10.8476 & 2.1482 \\
\hline 6 & 18 & 11.7647 & 12.6744 & 1.8268 \\
\hline 7 & 7 & 4.5752 & 14.0900 & 1.4156 \\
\hline 8 & 4 & 2.6144 & 15.9567 & 1.8667 \\
\hline 9 & 2 & 1.3072 & 18.5050 & 2.5483 \\
\hline & $\mathbf{1 5 3}$ & & & \\
\hline
\end{tabular}


Tabel 06. Persentase Berat Daging, Rata-rata dan Pertambahan Berat Daging Berdasarkan Kelas ukuran

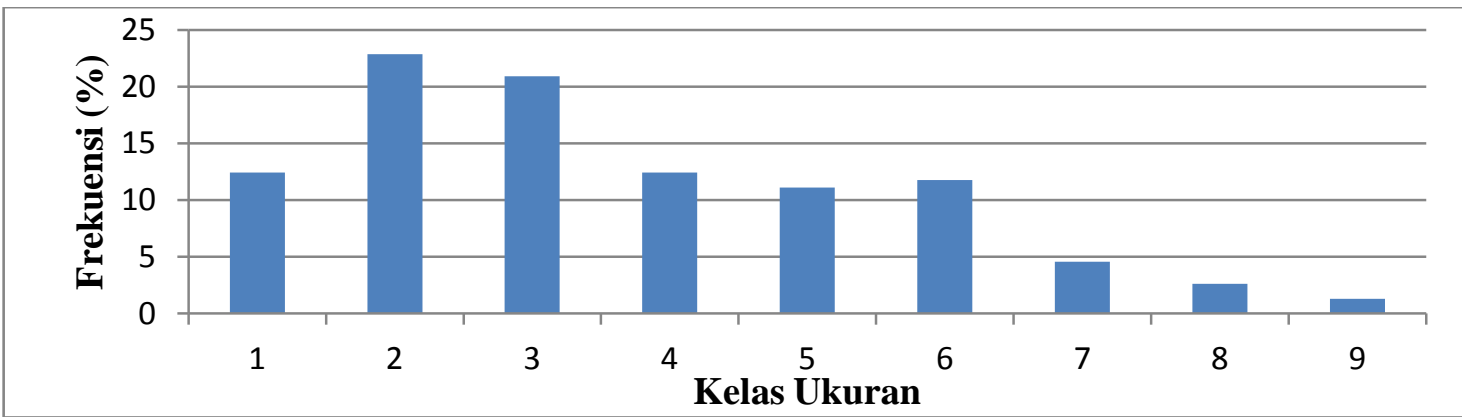

Gambar 11. Persentase Sebaran Berat Daging Berdasarkan Kelas Ukuran

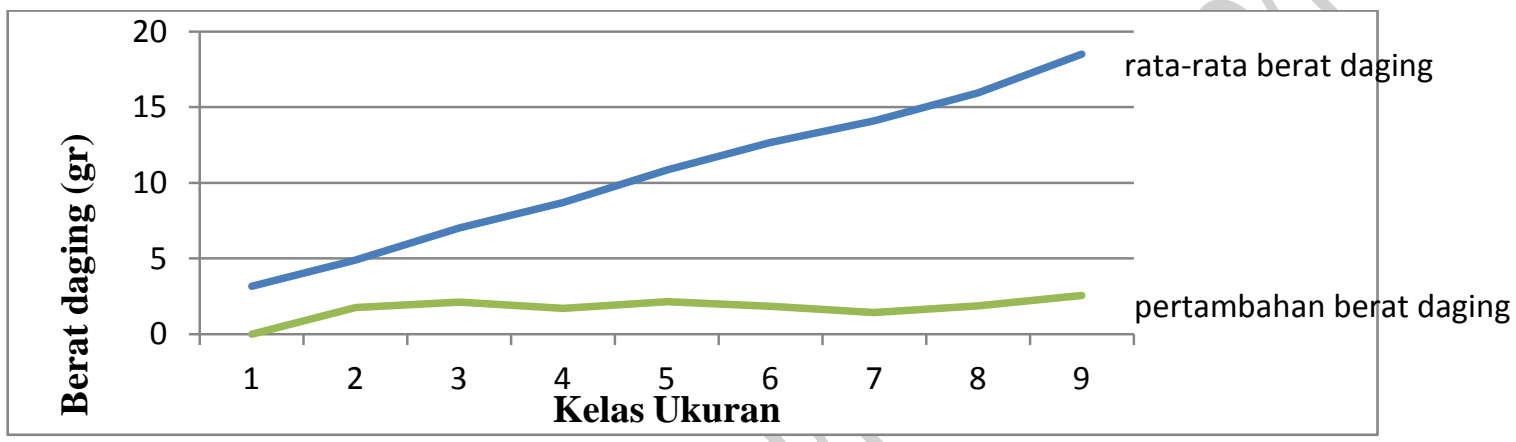

Gambar 12. Rata -rata berat daging dan pertambahan berat daging berdasarkan kelas ukuran

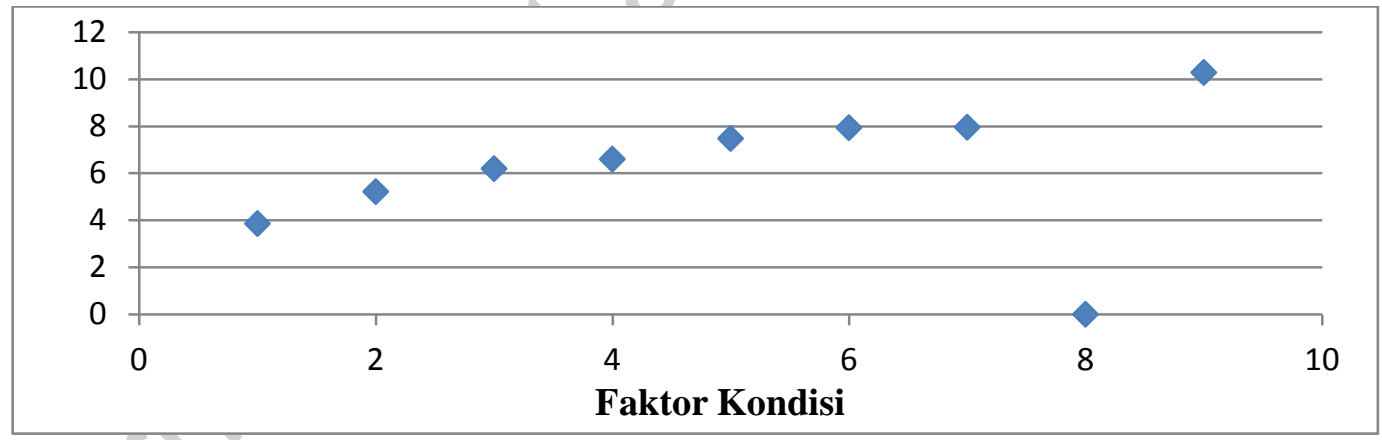

Gambar 13. Faktor Kondisi Dalam Bentuk Histogram 